\title{
米国の疾病予防支援サービス事業に 打ける保険技術の活用
}

小 林

篤

\section{ロアブストラクト}

米国で発展した, 慢性疾患の患者・患者予備軍の集団に対し, 合理的統合 的継続的なアプローチによって集団の疾病リスクを低減させる疾病予防支援 サービス事業について, 保険事業の保険技術の観点から検討した。合理的統 合的継続的なプロセスとして，対象とする患者集団を特定する「患者集団の 特定」, 患者集団に属する者のリスクの程度を判断し, リスクの大きさに応 じてグループに分ける「階層化」, 階層化したグループ別に患者と医療プロ バイダーへ「働きかけ」を行い，どのような効果をあげたか測定する「効果 測定」, 再アセスメントして継続するプロセスがある。これらのプロセスに は，保険事業で形成された保険技術と同じ機能を有する技術が使われている。 保険事業の事業形態に関し, 保険事業において蓄積された保険技術が応用可 能な領域が存在している，リスクの引受分散を行う事業とリスク低減を行う 事業を統合する事業形態の可能性があるなどの示唆が得られる。

\section{ロキーワード}

保険技術，疾病予防支援サービス，リスクの低減

\section{1 はじめに}

2005年には保険会社の関連会社として, 糖尿病などの生活習慣病の疾病予

*平成17年12月22日の日本保険学会関東部会報告による。

/ 平成18年 8 月 18 日原稿受領。 
米国の疾病予防支援サービス事業に扔ける保険技術の活用

防支援を行うサービス会社がいくつか設立された。これらの疾病予防支援を 行うサービス会社は，米国において発展したディジーズ・マネジメントを参 考にしている。

ディジーズ・マネジメントには，保険事業を成立させている基礎的な技術 が活用されている。本稿では，保険事業における技術がディジーズ・マネジ メントにおいてどのように活用され，どのような意義があるかを検討する。

米国のディジーズ・マネジメントは，日本ではこれまで疾病管理と訳され ることが多かった。しかし，ディジーズ・マネジメントが対象とするのは, 疾患にかかった患者だけでなく，疾患の予備軍までも対象にしているとの事 情があること，また管理という言葉からディジーズ・マネジメントにおける 本質的な要素である支援からかけ離れた印象を与えるとの事情があるので, 本稿では，米国のディジーズ・マネジメントを疾病予防支援サービスと呼ぶ ことにする。

本稿で用いる保険事業における技術, すなわち保険技術についてまず整理 しておこう。「保険技術」の用例としては次の例がある。最近の例は，山下 友信の『保険法』」における用例である。すなわち，「保険は大量の同質のリ スクを集積してその分散を四るメカニズムである」としたうえ，「これを実 現するために必要な技術が保険技術である。保険技術は，収支相等原則およ び給付反対給付均等の原則に集約される」としている1)。古い用例では，西 藤雅夫が，保険の技術を，保険企業によってなされる，純保険料から保険金 に至る資金交流の操作として捉えている2)。玉田巧は，保険技術として純保 険料算出に係わる収支相等の原則と給付反対給付均等の原則をあげている ${ }^{3)}$ 。 石田重森は，保険制度の基礎となる技術的な原則として，大数の法則，給付 反対給付均等の原則，危険同質の原則などをあげ，保険事業では大数の法則

1）山下友信『保険法』，有斐閣，2005年，p.58。

2）西藤雅夫『保険の経済理論』，法律文化社，1960年，p.84。

3）玉王田巧「保険の一般理論」亀井利明編『保険とリスクマネジメントの理論』, 法律文化社, 1992年, p.17。 
がよく作用し危険発生率の測定が正確になされ保険料率の適正な算定が実現 されることを指摘したうえで, 保険が科学的・合理的な制度とされる根拠と している ${ }^{4)}$ 。一方，「技術」は，例えば経営技術，教育技術などの用例が示 すように，合理的効果的な手段との一般的な意味でも使われる。また，科学 技術との用例が示すように，科学とその応用の意味に用いられることもある。 保険料算定には保険数理が用いられており，技術は科学的な研究成果を生か して実用に供する方法であると一般的に受け入れられている観念と整合的で ある。以上の整理をもとに，本稿では，保険技術を，リスクを引き受け被保 険者に保険保護を提供する保険事業を運営するために必要な技術と広義に考 えることにする。特に保険料算出に用いられている保険数理的な技術，保険 事故低減に用いられているロスプリベンションの技術に注目することにする。

本稿の構成は，次のと㧍りである。まず日本招よび米国で疾病予防支援サ 一ビスが事業化された背景および疾病予防支援サービス事業に関する研究動 向を概観したうえ，米国における疾病予防支援サービス事業の内容を保険技 術の観点から分析し，米国の疾病予防支援サービス事業における保険技術の 活用実態を検討して，その意義を考察する。

\section{2 疾病予防支援サービス事業成立の背景}

疾病予防支援サービスは，疾病予防を支援するサービスである。最初に， どうしてこのような新しいサービス事業が開始されることになったかを概観 する。つぎに，日本における疾病予防に関する大きな変化について言及する。

日本における疾病予防支援サービ久事業が開始された背景として，糖尿病 などの生活習慣病者の増加傾向が継続するという疾病構造の変化があげられ ている5 。米国における疾病予防支援サービスの生成発展にも，主として慢

4）石田重森「保険概論」庭田範秋編『保険学』，成文堂，1989年，p.17。

5）例之ば，生活習慣病の疾病予防支援を行うサービス会社のひとつは，高齢化 の急速な進展や生活習慣病を起因とした疾患群の増加等を事業開始の背景とし て説明している (http://www.e-hts.co.jp/service/)<2006年 8 月 8 日訪 問>。 
米国の疾病予防支援サービス事業における保険技術の活用

性疾患の増加傾向が継続していることが背景にあるとされている ${ }^{6)}$ 。日本で は生活習慣病対策と呼ばれ，米国では慢性疾患対策と呼ばれ，呼称は違うが ともに糖尿病をはじめとする, 慢性的疾患であり, かつ生活習慣に由来し生 活習慣改善が疾病の発症・重症化防止に有効である疾患である。この生活習 慣病が大きな問題となり，その疾患を対象にした対策が必要になったという 背景があって，疾病予防支援サービスが開始された。慢性疾患対策あるいは 生活習慣病対策が重要になったという傾向は, 日本と米国に限らない先進国 共通の傾向である。OECD 諸国では，一般的な健康水準の向上とともに， 慢性疾患の発生率も上昇し，今後もその傾向は続く見通しであると OECD の報告は指摘している7)。

日本では，疾病の発症・重症化防止は，以前から健康増進事業として取り 組まれてきた。生活習慣病対策は，1978年から開始された第一次国民健康づ くり対策で取り上げられ，市町村レベルで保健センターなどの施設の整備， 保健師，管理栄養士等の保健職の拡充が進められた。その後，1988年に開始 された第二次国民健康づくり対策を経て，2000年からは「健康日本 $21 」 と$ 略 称される国民運動が進められ，がん，心臓病，脳卒中，糖尿病等の生活習慣 病やその発症・進行に関与している生活習慣の改善等に関する課題に関して 具体的な目標を設定して事業が進められた。

企業の被用者が加入している健康保険組合は, 保険給付事業の他に保健事 業を行っている。保険給付事業は，被保険者や被扶養者の病気，けがなど に対して医療費を負担する事業であり，主たる事業である。健康保険組合は， この他に，被保険者とその被扶養者の健康の保持・増進をはかるために，健

6）欧州諸国のへルスケアビジネスおよびディジーズ・マネジメント研究会『米 国に於けるディジーズ・マネジメントの発展』損保ジャパン記念財団叢書 No.65，2003年, p.3。Norris, Susan, L., Russell E.Glassow, Michael M. Eggegau, Patrick J. O'Ccnor and David McCullloch, “Chronic Disease Management”, Disease Management and Health Outcomes, 2003, Vol.11 No.8, p.477.

7） OECD 編著『世界の医療制度改革』，明石書店，2005年，p.29。 
康づくりの啓発活動，健康診断，健康相談，保養所・体育施設の運営などの 保健事業を行っている。健康保険組合などの医療保険者が行う保健事業も, 健康増進事業のひとつである。

2005年に政府・与党医療改革協議会が取りまとめた，「医療制度改革大綱」 では，予防の重視を明確に打ち出し，生活習慣病予防のための取組体制を強 化するために，都道府県の健康増進計画の内容を充実すること，および上述 の保健事業を行ってきた健康保険組合，国民健康保険などの医療保険者に， 生活習慣病の予防について被保険者・被扶養者に対する効果的・効率的な健 康診断・保健指導を義務づけることにした。これを受けて，2006年に医療制 度改革関連法が立法され，生活習慣病に関して被保険者・被扶養者に健康診 断と生活習慣改善・受診勧奨などの保健指導を行うことが医療保険者の法定 義務になった。その結果，2008年度から40歳以上の全国民は，それぞれ加入 している医療保険者による健康診断（以下「健診」という）を受け，必要な 場合には保健指導を受けることになった。こうして，日本においては生活習 慣病対策が飛躍的に強化されることになった。

2006年に厚生労働省は，有識者による検討会を設置して，健康保険組合等 の医療保険者がその加入者の集団に対して実施する健診・保健指導プログラ ムの検討を行った。検討会においては，標準的な健診・保健指導プログラム のあり方について次の指摘がなされた。「糖尿病等の生活習慣病有病者・予備 軍の減少という観点から，内臓脂肪症候群（メタボリックシンドローム）の 概念を導入した標準的なプログラムの構築が必要である。具体的には，科学 的根拠に基づいた健診項目の見直しを行うとともに，生活習慣病発症・重症 化の危険因子（リスクファクター）の保有状況により対象者を階層化し，適 切な保健指導（「情報提供」「「動機づけ支援」，「積極的支援」）を実施するた めの判定の標準的な基準を導入することが必要である ${ }^{8)} 」$ ここで述べられ

8）厚生労働省「標準的な健診・保健指導の在り方に関する検討会」第 1 回健診 分科会（2006年 3 月 20 日）資料（http://www.mhlw.go.jp/shingi/2006/03/ s0320-7.html)。 
米国の疾病予防支援サービス事業における保険技術の活用

ている考え方は，医療保険者に加入している集団に対して健診によって危険 因子を判定し，判定結果に基づき発症リスクの程度に応じて集団をグループ 分け（階層化と呼ばれている）をして，リスクの程度に応じて，生活習慣改 善・受診勧奨の保健指導を行うものであり, リスクに応じた対処であるとの 特徴がある。

今般日本において強化された生活習慣病対策には，本稿で取り上げる，米 国の疾病予防支援サービスと共通する考え方がある。すなわち，生活習慣病 有病者・予備軍の減少を実現しようとする予防の考え方，保健指導などは 個々の対象者に対して実施されるが，対象者集団の状態を分析するなど集団 も対象にする考え方，リスクに応じて階層化し，リスクに応じて対象者に保 健指導を行うなどリスクを基本にする対処する考え方などである。また，そ の集団で生活習慣病が発症・重症化する数の減少を目指す取り組みは，その 集団の疾病リスクを低減させる取り組みとして捉えることができる。

\section{3 疾病予防支援サービス事業に関する研究動向}

米国で疾病予防支援サービスを指す，ディジーズ・マネジメントとの用語 が最初に用いられたのは，1993年である9 。それまで，米国では医療・保健 等のヘルスケアに関する取り組みは，患者の服薬，医師による手術などのコ ンポーネントをどう管理するかに関心があったが，デイジーズ・マネジメン トは，それを改め共通目標を達成するために専門分野を集結した総合的で継 続的なアプローチを採用し，医学的な状態に関するリスクに応じて集団を階 層化し予防的な見地から取り組むメディカル・マネジメントのひとつであ る ${ }^{10)}$ 。メディカル・マネジメントとは, 個々の疾病の診断治療に関するマネ

ジメントではなく, 医療機関, 医師・看護師・ケースマネジャーなどの医療

9) Armstead, Rodney C., John Jesitus and Sylva Dvorak, Medical Management: Disease Management, The Health Insurance Association of America, 2003, p.3.

10) McKendry, Mary J., Medical Management: An Overview, 2002, pp. 78-79. 
保健職を統合調整し，システムとして患者あるいは患者集団に適切な医療保 健サービスが提供されるようにマネジメントを行うことをいう。その後，急 速に発展し，1999年には医療保健関係者によって疾病予防支援サービスに関 する非営利団体 The Disease Management Association of America（以 下「DMAA」という）が組成された。DMAAは，各種集会大会を開催する などの活動の他に查読制度を採用した学会誌 “Disease Management”も 刊行している。

米国の製薬業界と薬学分野でも疾病予防支援サービスは，注目されている。 ディジーズ・マネジメントは，服薬指導をより効果的にシステム的に実施で きる手段としても活用できる。薬学関係でも疾病予防支援サービスは研究さ れてきた。この分野の研究が掲載されている学術誌として“Disease Management and Health Outcomes”がある。同誌は，1993年に創刊され， The International Society for Pharmacoeconomics and Outcomes Research（薬剤経済学およびアウトカム研究国際学会）と深い関係をもち つつ，各種の疾病予防支援サービスに関する研究成果が掲載されている。 疾病予防支援サービスが最初に発展した米国における研究動向を概観する と，疾病予防支援サービスが生誕し発展し続けた約 10 数年に，学術誌の刊行 に加えて学術的な研究書, 実務書が刊行されているが, 長い研究の蓄積があ る状況とはいえない。

日本においては，参考文献に掲げた，専門書，報告書が数点刊行されてい るだけであり，まだ研究の蓄積は多くない状況にある。

米国の疾病予防支援サービスでは，リスクの分析，予測モデルの構築運用 にアクチュアリーの活用が行われている。保険数理上解決すべき論点を，実 務的に技術的に検討した文献 ${ }^{11)}$ が公表されている他，予測モデルの活用に関

11) Kipp, Richard A., W. Charles Towner and Howard A. Levin, "Financial and Actuarial Issues," Disease Management-A Systematic Approach to improving Patient Outcomes, Todd, Warren E. and David Nash eds., 1997, pp.87-136. 
米国の疾病予防支援サービス事業における保険技術の活用

する研究集会も DMAA とアクチュアリー団体の共催で開催されている。

一方，保険研究の観点からの言及は非常に少ない。例えば，米国において も, 団体保険に関する研究書でメディカル・マネジメントの最近の動きのひ とつとして疾病予防支援サービスについて概要の説明がなされている程度で ある12)。

日本においても, 保険研究からの研究は見つけることはできなかった。保 険研究からの研究はほとんどないと考えられる状況である。

\section{4 米国における疾病予防支援サービス事業の内容}

多様な保険者が創意工夫をする専門会社から選択してサービスを購入する なかで，米国における疾病予防支援サービスは大きく発展した。米国におけ る疾病予防支援サービスを理解するために，最初に米国のへルスケアシステ ムの特徴について簡単に触れた後, 疾病予防支援サービスが目指すものとそ のプロセスについて説明する。

米国のへルスケアシステムの特徵は，いくつもあげることができる。その ひとつは，多様なモデルと異なる夕イプの保険者が存在していることである。 すなわち，保険者は，株式会社組織・相互会社組織の保険会社の他に， HMO (Health Maintenance Organization)，自家保険者としての雇用者， 政府組織（連邦政府あるいは州政府がメディケア，メディケイドを実施して いる）などがある。

また，保険会社などの保険者は，医療保険という保険商品を提供するだけ でなく，医療プロバイダーのネットワークを含めた，医療サービスを提供す る機能も果たすことが多い。米国のヘルスケアシステムには，健康保険プラ ン (Health Plan) という基本形がある（困 1 参照）。健康保険プラン (Health Plan) は, 健康保険プラン加入者, 保険者, 医療プロバイダーの

12) Johnson, Alison, "Medical Care Management," Group Insurance, Fourth ed., Bluhm, William F. ed., 2003, pp.967-971. なお, 同書第二 版（1996年刊行）では，疾病予防支援サービスは取り上げられていない。 
三者から構成される。保険者は, 加入者（患者）から収受した保険料を原資 として，医療プロバイダーに医療費を支払う。医療プロバイダーは，加入者 （患者）に医療サービスを提供した見返りとして，保険者から医療費の支払 いを受ける。保険者は，保険給付を行うだけでなく，医療プロバイダーのネ ットワークを組み立てて，加入者に医療サービスの提供が行えるようにする システムの構築運営までも含むことになっている。

\section{図 1 健康保険プランの基本形}

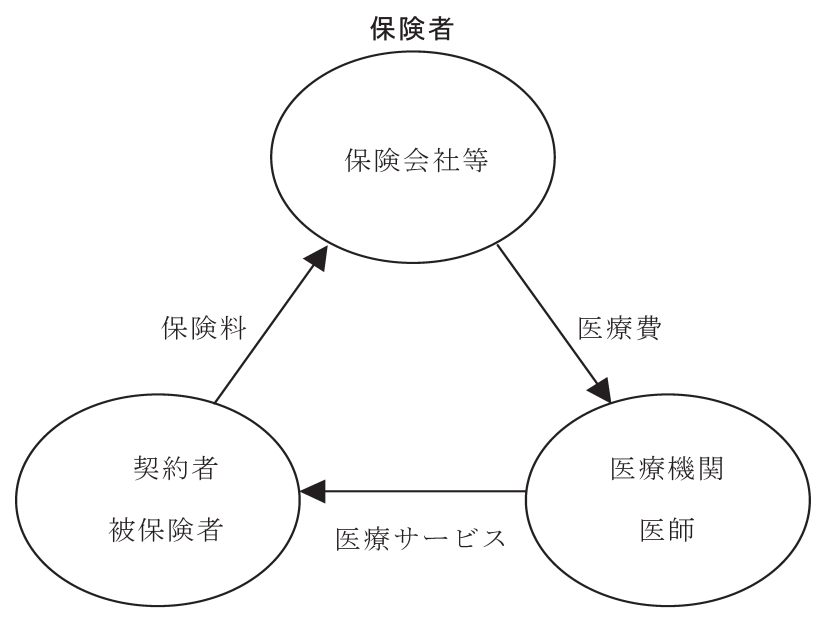

加入者 (患者)

(出典) 損保ジャパン総合研究所作成

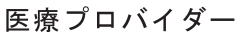

健康保険プランは，1990年代にマネジドケア型が主流となった。マネジド ケア型の特徵として次の点があげられる。拠出は，加入者一人あたりの想定 される年間の平均医療コストに加入者数を乗じた金額を，医療プロバイダー に前払いする方式であり，また，医療サービスの提供形態は，加入者は自由 に医療プロバイダーを選択できず，保険者が契約した医療プロバイダーのな かから選択をし，保険者は，加入者に対して医療機関・医師へのアクセスを 制限する他，医療プロバイダーに対しても診療内容，診療機関を管理する。 
米国の疾病予防支援サービス事業における保険技術の活用

このようなマネジドケア型の健康保険プランは，質の高い医療サービスを手 頃な価格で供給する仕組みであると説明されることがあるが，実際には加入 者，医療プロバイダーから強い反発を招き，政治問題，社会問題化してしま った。このため保険者はそれまでの利用を制限することを緩和するなどの対 応を進めた。医療費がかかる慢性疾患については，疾病が重症化してから対 応するのではなく疾病予防を眓ることが有効であるとの考えに立って，疾病 予防支援サービスが盛んになってきた。

保険者が，慢性疾患の患者・患者予備軍に対して，疾病予防を困ろうとす るならば，加入者と医療プロバイダーに働きかけを行うことになる。保険者 のなかには，自前で疾病予防プログラムを実施する例があるが，多くは外部 の疾病予防支援専門会社 ${ }^{13)}$ に委託している。それを困示したのが，図 2 であ る。

保険会社の機能として，疾病予防支援サービスを含むメディカル・マネジ メントが既に行われており ${ }^{14)}$ ，保険会社は疾病予防支援サービス専門会社を 利用することも多い。保険会社以外の HMO および自家保険者としての雇 用者も，疾病予防支援サービス専門会社を利用している。最近では，連邦政 府あるいは州政府が実施しているメディケア，メディケイドでも疾病予防支 援サービス専門会社の利用・試用が始まっている。

疾病予防支援サービスの対象は何か。対象疾病は，糖尿病，喘息，心臓病 等の慢性疾患である。疾病予防支援サ一ビス専門会社は，困 2 において医療 プロバイダーへの働きかけを行っている。すなわち，特定の疾病に関する診 療ガイドライン，ベストプラクティスに関する情報を提供することなどを通

13）疾病予防支援サービスを専門とするブローカーである，Disease Management Purchasing Consortiumが公表した資料である, Disease Management Industry Overview (1998-2006) には，189社のリストが掲載されてお り (このうち数社は大手保険会社の子会社となっている), Disease Management Purchasing Consortiumはこのリストは主要な専門会社を網羅してい るとしている。また，市場規模を 2005 年は約 1,181 百万ドルと見積もっている。

14) Johnson, Alison, op.cit. p.953. 


\section{図 2 保険者の疾病予防支援サービスの利用形態}

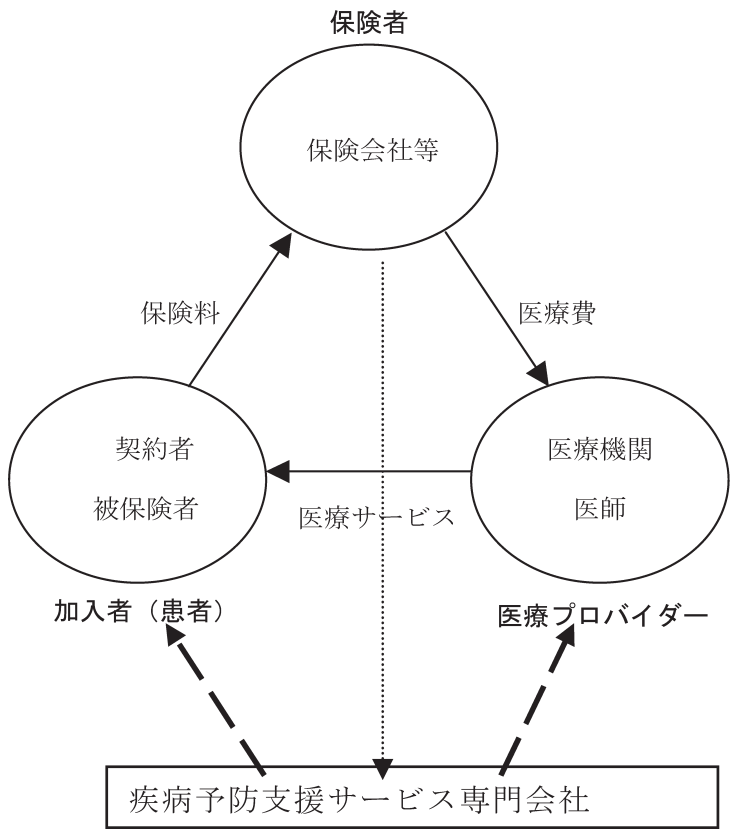

(出典) 損保ジャパン総合研究所作成

して，慢性疾患の患者・患者予備軍へ医療保健サービスを提供する医師，看 護師，栄養士に対し支援を行う。疾病予防支援サービス専門会社は，勿論患 者・患者予備軍に対して服薬指導や生活習慣改善の指導などを通して，患者 の自己管理能力が向上するように支援をする。疾病予防支援サービスの対象 は，患者・患者予備軍であるが，患者・患者予備軍の個々人だけでなく，患 者・患者予備軍の集団も対象にしている。

疾病予防支援サービスは，どのような目標を目指しているのか。疾病予防 支援サービスは，慢性疾患の予防を実現することを目指すものであるが，具 体的実務的には，どのような目標が設定されるのだろうか。例えば，慢性疾 患の減少は，入院患者数の減少で測る方法もあるので，入院患者数の減少を 目標に設定することもある。一般的には，財政面，医療面（clinical），患 


\section{米国の疾病予防支援サービス事業における保険技術の活用}

者満足度，患者教育効果などが使われている ${ }^{15)}$ 。財政面の例としては，疾病 予防支援サービスを利用することによって，利用しない場合と比較して疾病 予防支援サービスに要した費用も考慮して対象集団に要する医療費コストの 節減ができたかなどがある。また，医療面の例としては，対象集団全体とし て良好な服薬状況に改善したか，対象集団全体の平均血糖值が低下したかな どである。対象とした集団でどれだけ改善が実現できたかという観点で評価 される。米国連邦政府が，メディケアに疾病予防支援サービス導入の実験プ ロジェクトを公募した際に，応募する疾病予防支援サービス専門会社に求め られた達成目標は, Clinical quality (臨床治療の質), Beneficiary and provider satisfaction（被保険者，医療者の満足度），Savings to Medicare (メディケアの支出の削減) の三つであった ${ }^{16)}$

これらの目標を実現するために，疾病予防支援サービスには困 3 に示す， 合理的統合的継続的なプロセスが存在する。

最初のプロセスは患者集団の特定（Identification）である。ある保険者 に所属する全ての構成員から，ある疾患例えば糖尿病や喘息などの疾患に関

\section{図 3 疾病予防支援サービスのプロセス}

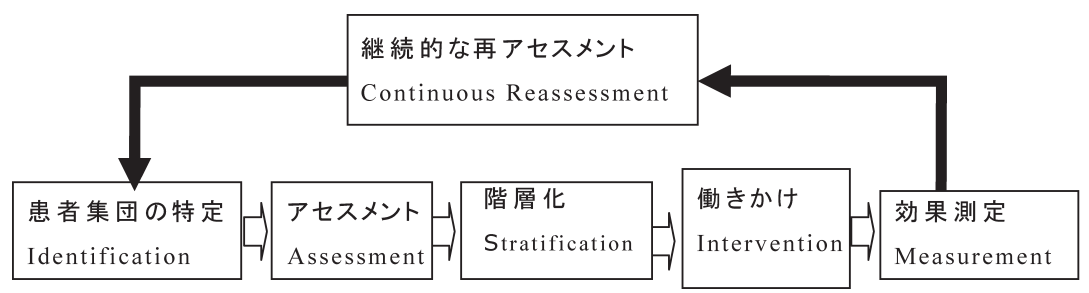

(出典) 損保ジャパン総合研究所作成

15) Howe, Rufus, The Disease Manager's Handbook, 2005, pp.23-25.

16) Medicare Program; Voluntary Chronic Care Improvement Under Traditional Fee-for-Service Medicare [CMS-5004-N], 69 Fed. Reg. 79, 22071 (2004). 
して疾病予防支援サービスの対象とすべき者を特定し, 疾病予防支援サービ スが対象とする患者集団を特定する。ただし，患者集団と称するが，患者予 備軍も含むことが多い。次のプロセスであるアセスメント（Assessment） は，特定された対象集団内の一人一人の状況を更に詳しく把握するための情 報を収集するプロセスである。情報収集は，直接対象者の家庭を訪問する方 式，電話を使って本人・家族にコンタクトする方式，所定のアンケート用紙 を郵送・回収する質問紙方式などがある。階層化（Stratification）のプロセ スでは，これらの方式で収集された情報，医療専門家の知見および予測モデ ルを用いて疾病予防支援サービスの対象として特定された患者集団に属する 者のリスクの程度を判断し，各個人のリスクの大きさに応じてグループに分 ける。これを階層化と呼んでいる。階層化を行うのは，医療保険スタッフ等 の人的な資源, 薬剂その他の物的な資源などの医療サービス資源を効率的に 使うべく，リスクの程度に応じて働きかけの内容や頻度を変えるためである。 具体的な例をあげれば，リスクが低い者を含む患者集団の全員には啓発的な パンフレット等を配布して糖尿病予防の情報提供をする一方，糖尿病の疾病 発症のリスクが高い者には専門スタッフを配置してコールセンターから電話 する，訪問看護を実施する等の積極的かつより費用が掛かる対応をする。こ うして，リスクの程度あるいは必要性の程度に応じて資源投入を行い，効率 的で効果的な疾病予防を実現しようとするのである。

階層化の際用いられる予測モデルは，将来の医療費支出，医療資源の利用 量を予測するものである。その役割は，リスクに関する指標に基づき対象者 が将来どのような医療保健サービスを利用することになりそうかを予測する

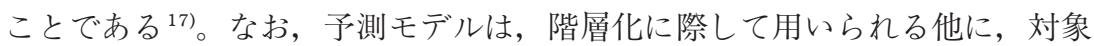
となる患者・患者予備軍を抜き出す患者集団の特定に際しても用いられてい る。予測モデルは，いくつかのタイプがあり，現在でも様々な夕イプの開 発・改良がなされている。予測モデルの構築運営には，アクチュアリーが担

17) Ian Duncan ed., Dictionary of Disease Management Terminology, First ed., 2004, p.124. 
米国の疾病予防支援サービス事業に损ける保険技術の活用

当することも多くある。

次のプロセスである，働きかけ（Intervention）には，患者への働きかけ と医療プロバイダーへの働きかけの二つがある。患者への働きかけの目的は， 患者の行動変容である。すなわち，患者の日常生活において患者が自分の疾 病の進行を防ぎ，健康を維持するために望ましい行動を選択するよう患者を 支援する (empowerment と呼ばれる) ことである。例えば，患者の理解が 不充分な場合，患者に教育を施し，食事や運動に関する生活習慣を自己管理 できるよう支援する。具体的な手段としては，訪問看護師が家庭訪問をして， 治療用具・測定用具の取扱い方および生活習慣・服薬の指導等を行う。この 他に，看護師等の医療保健スタッフがコールセンターから電話をして患者の 病状を定期的にチェックすることが行われる。また，患者やその家族は，症 状の急激な変化があった場合における対処の仕方，医師からの指示および薬 の用い方等について，いつでもコールセンターへ電話して相談できるサービ スを提供すること等も行われている。

その患者を担当している医療プロバイダーへの働きかけも行われる。これ は，疾病予防支援サービスが果たしている統合的な機能のひとつである，患 者への対応のために医療サービスを提供する関係者が協力できる体制を作り 出すという重要な機能である。具体的には, 主として医学情報の提供と患者 情報の共有が中心となっている。例えば，エビデンスベースの治療を行うた めに，個々の医師や医療機関はデー夕の収集および，しばしば改訂されるガ イドラインのフォローアップが必要である。疾病予防支援サービス専門会社 は，対象疾病についての情報を広く収集し，エビデンスベースの治療を実践 するための最新情報を医師や医療機関に提供している。疾病予防支援サービ ス専門会社は，またベストプラクティスに関する情報も収集し提供している。 当該疾病の治療に関するデー夕を広範に収集し権威のある専門家で組織され た委員会において検討のうえ，治療にあたってのガイドライン・ケア基準を 作成提供している。このように，その時点で考えられるべスト・プラクティ スに関する情報を関係者（患者，医療プロバイダー）が共有できるよう，必 
要な情報提供を行っている。患者と常に連絡を取れる状況にある疾病予防支 援サービス専門会社には，患者の健康状態の推移と現状に関するデータが集 積されているので，医師にとってもこの情報のフィードバックを受けて通常 の通院受診時点の記録に加え， 日常の変化も把握でき治療方針確認・検証に 役立てることができる利点がある。

働きかけのプロセスの次は，働きかけがどのような効果をあげたか測定す る効果測定（Measurements）である。目標として効果が達成されたかを測 定する。測定は，概ね次の三つがある。すなわち，医療面の評価である服薬 の遵守状況・臨床検查結果，経済的評価である医療コス卜の削減状況・医療 機関の利用状況コスト，および満足度評価である患者満足度・医師医療機関 満足度等である。この他にも測定項目を設けることが行われている。効果測 定をその次の改善プロセスに繫げていることが，疾病予防支援サービスの特 徵のひとつになっている。

改善プロセスの存在は，継続的な再アセスメント (Continuous Reassessment）にはっきり現れている。再度アセスメントしその結果により，階層 レベル変更の要否を検討し，次のサイクルにおいてより効果的で効率的な働 きかけが実現できるように，働きかけの内容・頻度などを改善することが行 われる。継続的な再アセスメントには，個人のレベルと集団のレベルの二つ がある。個人レベルで患者個人について働きかけの効果測定に基づいて当該 患者の階層を見直すという意味での再アセスメントであり，集団レベルでは プロセス自体のパフォーマンスを定期的に検証して改善を継続するという再 アセスメントである。

\section{5 米国の疾病予防支援サービス事業のプロセスと保険技術の活用}

疾病予防支援サービスでは，以上述べた，合理的統合的継続的なプロセス を繰り返すことにより，慢性疾患の発症予防・重症化予防を，限られた医療 保健資源を効率的に利用して，効果をあげることを目指している。米国の疾 病予防支援サービスは，保険者が直接組み立てることもあるが，多くは疾病 


\section{米国の疾病予防支援サービス事業における保険技術の活用}

予防支援サービス専門会社が提供する形態を取っている。保険者でない疾病 予防支援サービス専門会社が提供する疾病予防支援サービスのプロセスでも， 保険事業で形成された保険技術と同じ機能を有する技術が使われている。第 一に階層化に関する技術，第二に予測モデルに関する技術，第三にロスプリ ベンションに関する技術である。

保険事業で形成された保険技術の観点からみるならば，階層化は，純保険 料を算定する際にリスクを等級に区分することと同じ機能である。疾病予防 支援サービスにおける階層化は，保険事業においてリスクを区分しそれぞれ のリスクに応じた純保険料を算定し，給付と反対給付を均衡させる機能と同 様に考えることができる。ただし，疾病予防支援サービスの階層化は，次の プロセスにおける働きかけを効果的に効率的に行うためであり，保険事業に おいてリスクに応じて純保険料を算定する目的とは異なっている。

次に，予測モデルについて考える。予測モデルは，過去の実績デー夕をも とに将来の医療費支出，医療資源の利用量を子測する。過去の実績デー夕の 例としては，医療費請求データ，薬剂費請求データ，年歯・性別等のデモグ ラフィックデータなどがある。予測モデルは，階層化とその後の働きかけを 実施するときに，対象者のリスクを判断するために用いられる。予測モデル が求める対象者のリスクは，現時点までのリスクではなく，将来のリスクで ある。つまり，将来のリスクを予想する機能がある。保険事業では，純保険 料は，過去の事故発生の実績データをもとに算定される。純保険料を算定す るときからみて将来の時期に，純保険料は適用されるから，純保険料の算定 は，将来のリスクを算定することである。将来のリスクを予想する機能は， 同じと考えられる。しかし，両者には次の違いがある。純保険料の算定は， 営業保険料を算出し保険の引受を行う目的でなされる。純保険料は，リスク は被保険者，家屋，自動車などの単位をもって示された価格の指標であり， 保険引受に際して契約者共通に適用される指標である。一方，予測モデルで は，どの場合でも当てはまる単一・共通の指標が用いられることはなく，リ スクの程度を示す，複数の指標が用いられることが多い。例えば，医療資源 
の利用を示す，医療費支出，薬剂使用量，入院患者数・日数などの指標であ る。

第三のロスプリベンションに関する技術は，どうか。個別の保険技術に着 目するのではなく，リスクを制御低減する取り組み全体に係わる技術として 考えてみよう。保険事業においてはリスクを引受分散する業務が主たるもの だが，同時にロスプリベンションと呼ばれる防災活動も行ってきた。疾病予 防支援サービスは，予防を実現するための活動であり，集団の疾病リスクの 低減を実現することが目的になっている。両者は，ともにリスクを計量評価 し，リスクを保有する人・ものに対してリスクを低減するように当事者を支 援する点では共通であり，そのために様々な働きかけの技術を磨いてきてい る。ただし，疾病予防支援サービスではリスクの低減が究極の事業目的であ るのに対し，保険事業ではリスクの引受分散に付随する業務となっている点 が異なっている。また，疾病予防支援サービスでは，継続的に改善を図る点 が強調されていることが特徵になっている。

\section{6 結語}

これまで疾病予防支援サービスにおける保険技術の活用を検討した。ここ で行った保険技術の活用の検討は，保険事業から疾病予防支援サービス事業 に進出して保険技術が活用された実例の検討ではなく，保険技術の活用が可 能だという検討をしたのである。

米国の疾病予防支援サービス事業では，保険数理の専門家であるアクチュ アリーが予測モデルなどの活動に参画し，重要な担い手になっている。保険 数理的なアプローチが可能であり，重要な事業領域が，保険事業以外にも存 在していることを示す事例であろう。

以上の検討から，保険事業の事業形態に関する示唆を得ることができるだ ろう。ひとつは，保険事業において蓄積された保険技術が応用可能な領域が 存在していることである。保険事業は専業とし他業の兼業を禁止する規制が 民間保険事業では一般的である。しかし，もし蓄積してきた保険技術を生か 
米国の疾病予防支援サービス事業における保険技術の活用

せるケイパビリティがあれば，保険事業以外にも保険技術を転用できる可能 性がある。もうひとつは，リスクの引受分散を行う事業とリスクの低減を行 う事業の統合の可能性である。米国において健康保険プランのなかで，保険 者は保険リスクを引受け保険金を支払う医療保険のなかで，疾病予防支援サ 一ビスを外部から調達してリスクの低減を図っている。日本でも健康保険組 合などの医療保険者が，保険給付事業と並んで疾病予防支援の保健事業に取 り組むことになった。保険事業における保険技術と疾病予防支援サ一ビスに おけるいくつかの技術は，共通である。今後，リスクの引受分散を行う事業 とリスクの低減を行う事業を統合し，資源利用の効率性の向上に寄与する事 業形態が展開する可能性がある。

(筆者は損保ジャパン総合研究所勤務)

参考文献

・欧州のへルスケアビジネスおよびディジーズ・マネジメント研究会『米国におけ るディジーズ・マネジメントの発展』, 損保ジャパン記念財団叢書 No.65, 2003 年

・松田晋哉・坂巻広之編著『日本型疾病管理モデルの実践』，じほう社，2004年

・中浜隆『アメリカの民間医療保険』, 日本経済評論社，2006年

・磯部広貴『アメリカの民間医療保険』，保険毎日新聞社，2006年

Todd, Warren E. and David Nash eds., Disease Management-A Systematic Approach to improving Patient Outcomes, Jossey-Bass, 1997.

McKendry, Mary J., Medical Management: An Overview, America's Health Insurance Plans, 2002.

Munden, Julie ed., Disease Management for Nurse Practitioners, Springhouse, 2002 .

Armstead, Rodney C., John Jesitus and Sylva Dvorak, Medical Management: Disease Management, The Health Insurance Association of America, 2003 .

Bluhm, William F. ed., Group Insurance, Fourth ed., ACTEX Publications, 2003.

Disease Management Association of America Outcomes Consolidation Steering Committee, Disease Management Program Evaluation Guide, 
First ed., Disease Management Association of America, 2004.

Ian Duncan ed., Dictionary of Disease Management Terminology, First ed., Disease Management Association of America, 2004.

Norris, Jason, ed., Predictive Modeling in Disease Management, National Health Information, 2004.

Howe, Rufus, The Disease Manager's Handbook, Jones and Bartlett Publishers, 2005.

Huber, Diane L., Disease Management, Elsevier Saunders, 2005. 